\title{
Changes in Labour Market and Domestic Agriculture
}

\author{
Kamal Karunagoda*
}

\begin{abstract}
Sri Lanka's economy has undergone significant structural changes during the past two decades. The manufacturing and services sectors show a considerable growth during this period and these changes in the economy seem to have had a greater influence on domestic agriculture. Sri Lanka's rural areas have witnessed the co-existence of rising wage rates of domestic agricultural sector workers with relatively high unemployment levels. The real price of agricultural output shows a declining trend while the real wage rate in domestic agriculture shows an increasing trend. This study examines the influence of the expansion effect of non-agricultural sector on the real wages of the domestic agriculture during the post reform period. Engle and Granger methodology is used to determine the relationship between real agricultural wage rates, capital formation in non-agriculture and wage rate of export agriculture. The results indicate the presence of a long-term relationship between wage rate and capital formation in the non-agriculture sector. Increase in labour productivity, suitable farm mechanization and institutional changes related to land and labour would help to mitigate the negative influence of rising wage rates on domestic agriculture.
\end{abstract}

\footnotetext{
* The author is affiliated to Socio-economic and Planning Center, Department of Agriculture, Peradeniya.
} 


\section{Introduction}

The unemployment rate in Sri Lanka has been quite high and solving unemployment is an important policy objective of every government. The economic reforms, foreign investments, export processing zones, large scale foreign aid funded infrastructure developments assisted the reduction in persistent double digit unemployment. The proportion of workforce involved in paid employment shows a steady growth after the reforms, especially in manufacturing, trade, and services. Improved access to higher education reduced the labour force participation in the 10-19 year age group. On the other hand, participation in the 25-54 age groups has steadily risen. In the case of the Domestic Agriculture Sector (DAS), smallholders represent the majority of the agricultural workforce. Commercialization of domestic agricultural sector and promotion of labour intensive high value crops among small holders have replaced the traditional labour exchange system between farms to wage employment. Despite the prevailing high unemployment in rural areas, the real wage rate of domestic agricultural labour shows an increasing trend. Structural adjustments has an effect on the labour market while labour market plays an important role in the labour intensive DAS. This study seeks to investigate the impact of structural changes on the DAS labour market.
This analysis on labour market is motivated by lack of previous empirical analysis regarding Sri Lanka's labour market behaviour. The evaluation of integration of agricultural wages with the expansion of non-agricultural sector is the main objective of this study. Section two provides a brief outline of the behaviour of agricultural labour market. An overview of economic reforms and agricultural workforce of Sri Lanka is presented in section three. The method applied in this study and the empirical estimation procedure are presented in section four and five respectively. The last section provides policy implications and suggestions for further research.

\section{Behaviour of Agricultural Labour Market}

The prevalence of rising wage rates for hired agricultural workers with widespread unemployment give rise to the question whether neoclassical theory of economics is inoperative in determining the agricultural wages. Classical economists believed that wages are determined by what is required for subsistence consumption (Lewis, 1954), which is known as subsistence wage theory. However, this theory fails to provide an exact mechanism of wage formation under an environment without minimum-wage laws or without organized labour unions for collective bargaining. Nutritionally based efficiency wage 
hypothesis (Leibenstein, 1957; Majumdar, 1959) tries to link the consumption requirement that is required to work effectively. However, no convincing evidence has been provided to support this hypothesis. Ahmed (1981) tried to explain the wage determination in Bangladesh using the demand and supply of casual labour. This study tries to relate prevailing unemployment to voluntary unemployment of group of rural people which is related to social status. However, this study indirectly supports the subsistence wage hypotheses that "a wage which will depend on the food prices rather than the demand and supply of labour". Furthermore, it outlines the structural factors that affect the demand and supply of casual workers and found that the wage rates were positively related to the inequality of land distribution, cropping intensity and tenancy and negatively related to the production uncertainty and the proportion of agricultural wage labourers.

The increasing wage rate has an economic meaning of higher demand at prevailing supply. Dixit and Rob (1994) attributed histeresis to unwillingness of labour to move between sectors. Histeresis refers to the failure of a phenomenon to reverse itself once its initial cause is removed (Dixit, 1989). Richards and Patterson (1998) used this argument to explain labour market disequilibrium that agricultural workers, once induced to move out of the non-agricultural sector, are hesitant to return even though the relative returns to doing so may make such a move rational. The reason for this reluctance is that workers make an irreversible investment in human capital specific to non-agricultural sector. Therefore, apparent shortage may be due to workers that are in the labour force but do not choose to take agricultural jobs.

Reported higher unemployment in Sri Lanka has been attributed to unrealistic expectation for public sector jobs, stringent job security regulations and extended family support during job searching period. The majority of unemployed in Sri Lanka is supposed to be voluntary type and not due to lack of employment (Seers, 1971; Rama, 2003). Rama (2003) indicated that Sri Lankan job seekers spent extended time period on searching good jobs and shun bad jobs due to artificial gap between good and bad jobs. But, this study does not give detail information on the qualities of good jobs and bad jobs and their relevance to agricultural labour market. However, this study indicates that level of education has a strong influence on voluntary unemployment. Larson and Mundalak (1997) agued that wage rate provide an inadequate picture because of quality differences. Beyond this, seasonal wage rates can conceal the fact that in some seasons 
there is no work and hence wage data do not indicate the overall labour availability or the relative scarcity of labour. They suggested dividing the sectoral income by sectoral labour force to capture the employment situation in agriculture to a large extent.

\section{Liberal Economic Reforms and Agricultural Workforce}

The total workforce in Sri Lanka has increased by $24 \%$ during the period of 1977 to 2001 . About $36 \%$ of the workforce remained in agriculture in 2000, compared with $52 \%$ in 1977 (Table 1). However, total labour force reduction in agricultural sector is marginal $(6 \%)$. The proportion of workforce engaged in services rose from $34 \%$ in 1977 to $47 \%$ in 2002 while the proportion of workers in the industrial sector increased from $14 \%$ to $17 \%$ during the same period (Table 1).

The distribution of landholdings is identified as an influential factor on wage determination (Ahmad 1981). The area under commercial smallholding sector (holdings less than 8 ha), which represent about $90 \%$ of total agricultural holdings, has increased by $6.7 \%$ during the period 1982 to 2002. The area expansion was mainly due to the land development under Mahaweli river diversion programme. During the same period, the total number of holdings has increased by $122 \%$ while average size of the small holding sector has decreased from $1.97 \mathrm{ac}(0.8 \mathrm{ha})$ in 1982 to $1.2 \mathrm{ac}(0.5$ ha) in 2002 (Table 2). This indicates the degree of land fragmentations owing to demographic pressures and also gives an indirect measure of workforce that remains in agriculture.

The majority of the export agricultural sector (EAS) workforce (plantation workforce) comprise of descendants of immigrant South Indian labour force who have later gained citizenship. The large plantations have a resident labour force and their wage rates are determined largely by institutional and trade union actions. The minimum wage policy, which has been in operation since 1941, has had a little effect on wage formation in the export or domestic agricultural sectors (CBSL 1998).

Agricultural labour productivity shows a positive growth during post reform period (Figure 1). Income per labour has increased during this period and this is attributed to the technological development (green revolution, mechanization, and among others), reduction in agricultural workforce, expansion of land area, and increase of area under irrigation.

The nominal wages of the DAS sector as well as other sectors show an increasing trend (Figure 2). The real wage rate of the DAS shows a downward trend until 1990 but since 
Table 1: Labour Force Participation (000')

\begin{tabular}{lllllll}
\hline Category & 1977 & 1980 & 1985 & 1990 & 1995 & 2000 \\
\hline Agriculture & 2415 & 2361 & 2495 & 2361 & 1967 & 2267 \\
& $(52)$ & $(50)$ & $(49)$ & $(47)$ & $(37)$ & $(36)$ \\
Industry & 638 & 652 & 715 & 749 & 877 & 1107 \\
& $(14)$ & $(14)$ & $(14)$ & $(15)$ & $(16)$ & $(17)$ \\
Services & 1594 & 1660 & 1922 & 1937 & 2513 & 2968 \\
Total employed & $(34)$ & $(36)$ & $(37)$ & $(38)$ & $(47)$ & $(47)$ \\
$\begin{array}{l}(000 ') \\
\text { Total labour force } \\
\left(000^{\prime}\right)\end{array}$ & 5647 & 4673 & 5132 & 5047 & 5357 & 6342 \\
\hline
\end{tabular}

Sources: CBSL, 1998 and 2000.

Notes: Industry includes mining and services include construction. Figures in parenthesis are percentage of total employed.

Table 2: Number of agricultural holdings: smallholding sector

\begin{tabular}{lccc}
\hline & 1982 & 2002 & Increase \\
\hline Agric extent (million ac) & 3.54 & 3.78 & +0.24 \\
No of agric holdings (million) & 1.79 & 3.26 & +1.47 \\
\hline
\end{tabular}

Source: Census of Agriculture Sri Lanka, 2002.

Notes: Small holding sector consist of holding less than 20ac. The number of agricultural holdings has increased in every districts of Sri Lanka while the size has decreased in Colombo, Gampaha, Kalutara, Kandy, Kegalle and civil war affected districts (Jaffna, Killinochhi, Mannar, Vavuniya and Mullaitivu) in Northestern province.

1990 it shows an increasing trend (Figure 3). The EAS wage rates had been on an upward trend until mid 1990s and after that it shows a clear downward trend. Industry and commerce, and services sectors recorded higher growth rate during the post-reform period. Despite this growth, real wage rates of these sectors have been decreasing. The increasing wage rate of the DAS despite relatively higher rural unemployment and poverty levels indicate the prevalence of histeresis related to agricultural employment in Sri Lanka. The labour unions of plantation sector have traditionally been strong and various labour legislations, such as minimum wage, minimum number of working days and hours, have been adopted to protect the rights of resident labour force in the EAS. The occupational mobility of the export-agricultural 


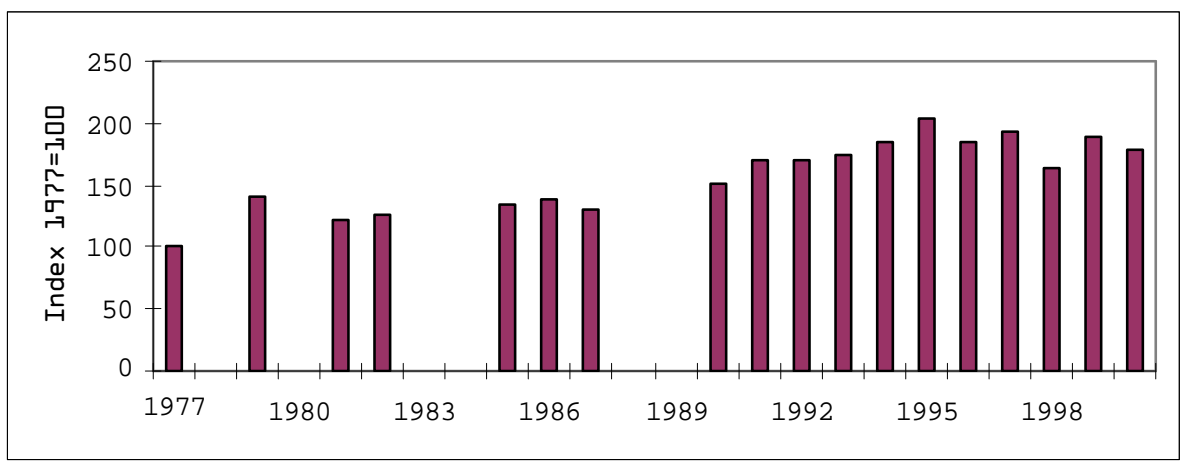

Figure 1: Agricultural productivity (GDP/Agricultural workforce) Source: Calculated from data in CBSL

labour force was largely restricted by linguistic and cultural barriers. This situation could limit the inter-sectoral migration of plantation workers. The EAS labour force, therefore, may have shown less response to increased labour demand in fast growing sectors. Farmers in smallholding sector have not been well organized and government interests had been directed to improve the welfare of smallholders at the expense of consumers.

The DAS is characterized by smallholders with an average land area of less than 1 ha. On these farms, labour requirements are concentrated in a few months for rice cultivation. Diversification of farm production with high value crops has significantly increased the on-farm

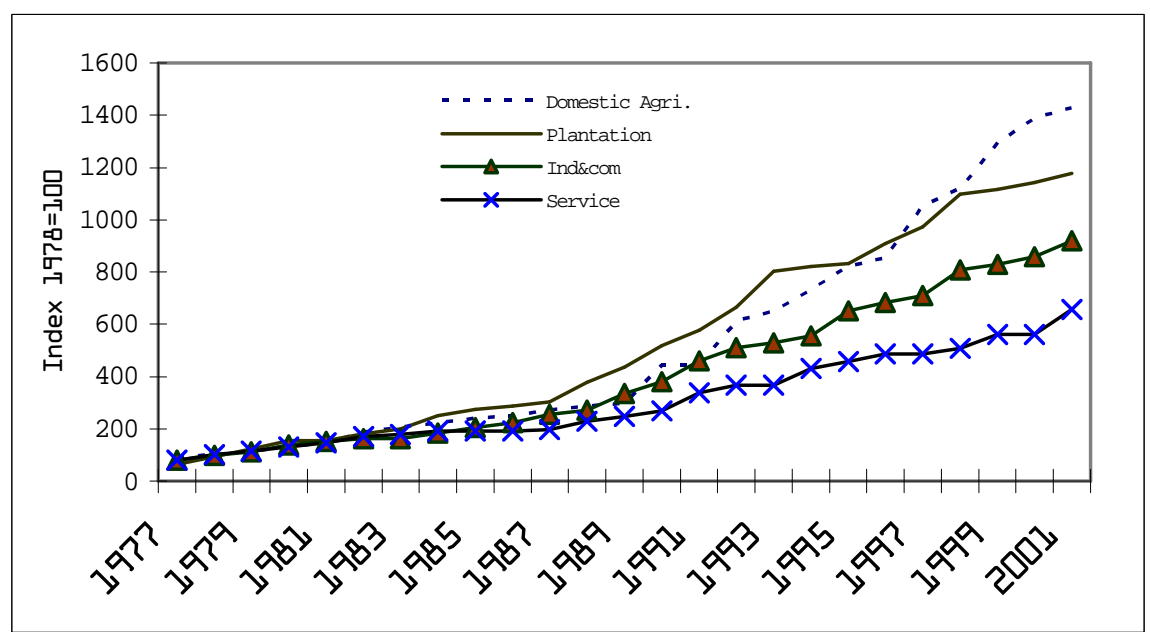

Figure 2: Nominal Wage Rates (Index 1979=100) 
Source: Estimated from data in CBSL and COC

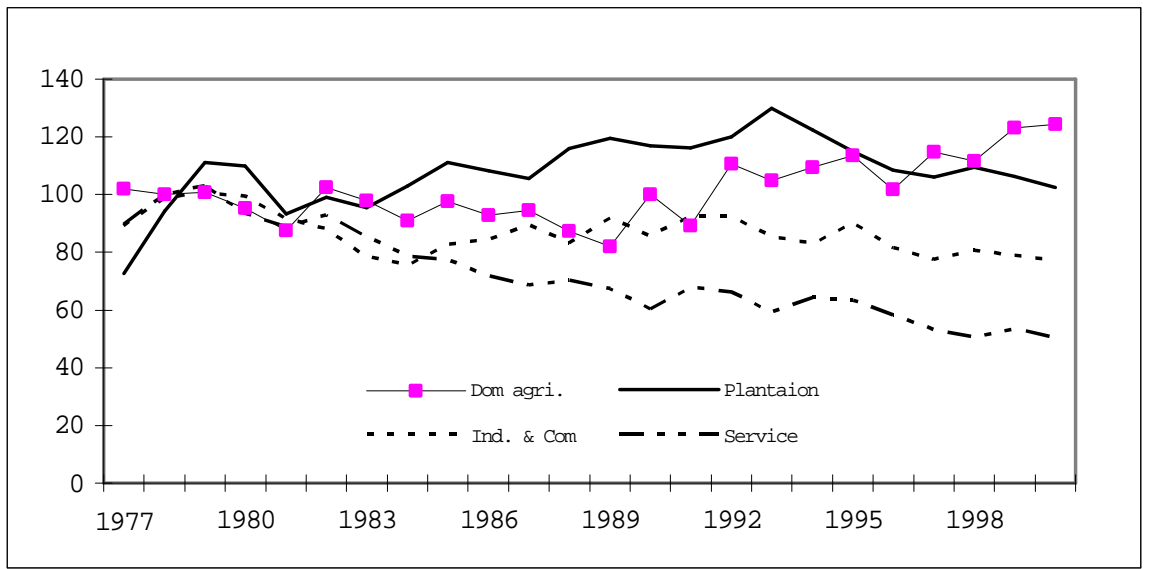

Figure 3: Real Wage Rates (Index 1979=100)

Source: Estimated from data in CBSL and COC

labour usage. According to a study by Wikramasinghe et al. (1994), 3040 per cent of farmers work as wage labourers on others farms and the degree of such engagements is higher in predominant agricultural districts. According to the seasonal surveys of the Department of Agriculture (DOA), there has been a reduction in total labour usage in rice cultivation, the main crop of the DAS, in all agricultural districts. The use of hired labour in rice cultivation shows a proportionate reduction and this indicates the lowering of demand for hired labour. This reduction may be attributed to farm mechanization, farmers' response to increasing wage rate and decreasing real producer prices. In the case of the import competing crop sector, labour intensiveness of crop production has

Table 3 : Changes in labour usage (labour days per acre) in rice cultivation: 1977-2000

\begin{tabular}{llllll}
\hline & & Period & & & \\
District & $1978-79$ & $1984-85$ & $1990-91$ & $1994-95$ & $2000-01$ \\
\hline Ampara & 61 & 44 & 38 & 35 & 30 \\
Anuradhapura & 58 & 38 & 44 & 42 & 32 \\
Polonaruwa & 73 & 60 & 52 & 46 & 30 \\
Kalawewa & 59 & 41 & 52 & 40 & 33 \\
Hambantota & 56 & 40 & 43 & 40 & 35 \\
Gampaha & 52 & 54 & 53 & 44 & 38 \\
Matale & 57 & 57 & 55 & 55 & 48 \\
\hline
\end{tabular}

Source: Socio economic and planning center, Department of Agriculture, Sri Lanka 
not changed. The supply responses of the DAS show a significantly negative relationship with agricultural wage (Karunagoda et al. 2005). The changes in the economic environment can have strong direct and indirect impact on the DAS's labour market which is reflected by the higher agricultural wages. Increase in adoption of labour saving technological innovations in agricultural production, decrease in family size, land fragmentation and rise in labour force participation in off-farm jobs may have contributed to reduction of labour supply on farms

\section{Methods: Cointergration and Error-Correction Representation}

The post-reform period is associated with sustained economic growth and gradual reduction of unemployment in Sri Lanka. Establishment of export processing zones, foreign aid funded large infrastructural developments, increased public recruitments, and increased foreign job opportunities substantially contributed to reduce unemployment. The labour force in the DAS has not been successfully organized and there are no empowering legislation applied to the DAS workforce. Open economic policies may have opened wide opportunities for farm families to seek employment outside rural areas. An increase in real wage rate of the DAS may be an indication of higher labour migration from the DAS to the fast growing sectors. Lower costs of transportation have increased commuting distance from rural areas to urban centers. If the rural labour market is assumed to be competitive, the demand for agricultural labour $\left(D_{L A G}\right)$ may be expressed as:

(1)

$D_{L A G}=f\left(P_{A T}, W_{A G}, K_{A G}\right)$

Where, $\mathrm{P}_{\mathrm{AT}}$ is the price of agricultural output, $\mathrm{W}_{\mathrm{AG}}$ is the wage rate and $\mathrm{K}_{\mathrm{AG}}$ is the capital formation in agriculture. Inter-sectoral migration may be induced by the wage (income) differential between urban and rural sectors. Agricultural labour may migrate to urban areas, if the cost of migration and expected wage rate is higher than $\mathrm{W}_{\mathrm{AG}}$ (Larson and Mundalak, 1997). Real wage rate in the DAS has been increasing during the 1990s, while real wages for non-agricultural sector shows a decreasing trend during the same period. Widening gap between rural and urban wage rates indicates that the wage difference may not be the sole criterion in determining intersectoral migration. Seasonality of agricultural income and uncertainty associated with agricultural production may provide strong impetus for labour movement out of agriculture to areas where such risks are lower. Further, social status and working conditions in nonagricultural jobs are generally much better than that of agricultural jobs. Voluntary unemployment in Sri Lanka is much higher and it shows strong relationship with level of 
investment on human capital (Rama, 2003). Therefore, there is a strong possibility for labour to move out from agriculture in response to opportunities arising in the nonagricultural sector (NAS). It was assumed that the level of capital formation in the non-agricultural sector indicate the level of such opportunities available for the rural labour force. The aggregate labour supply is expressed as a function of $\mathrm{W}_{\mathrm{AG}}$, wage rate of the NAS $\left(\mathrm{W}_{\mathrm{NA}}\right)$, capital formation in non-agriculture $\left(\mathrm{K}_{\mathrm{NA}}\right)$. Thus the market of agricultural labour can be expressed as:

(2)

$$
\begin{aligned}
D_{L}\left(P_{A T},\right. & \left.W_{A G}, K_{A G}\right)= \\
& S_{L}\left(W_{A G}, W_{N A}, K_{N A},\right)
\end{aligned}
$$

The reduced from of the wage equation can be formulated as:

(3)

$$
\begin{aligned}
& \mathrm{W}_{\mathrm{AG}}= \\
& \left(\mathrm{P}_{\mathrm{AT}}, \mathrm{W}_{\mathrm{NA}}, \mathrm{K}_{\mathrm{NA}}, \mathrm{K}_{\mathrm{AG}}, \mathrm{Z}\right) \\
& +++++
\end{aligned}
$$

Where, signs below show the expected relationship with $\mathrm{W}_{\mathrm{AG}}$ with independent variables and $\mathrm{Z}$ stands for other variables not included in the equation. Wage formation in highly unionized EAS is believed to have a strong influence on the wage formation in the DAS. Increase of price of output and improvement of terms of trade induce farmers to increase farm output and this in turn increase the labour demand. Some studies in developing countries have shown that agricultural wage rate is related with the price of staple food (Ahmad, 1981; Sah and Stiglize, 1987). The technological changes in DAS can be categorized into two: yield improvement and labour saving technology. It is assumed that yield improvement technology is labour neutral. However, yield improvement technology indirectly influence agricultural wage rate as increase of labour productivity tends to increase wage rate (Boyce, 1984). The growth in rural population increases the supply of labour. However, labour supply to agriculture is not only determined by the growth but also by the availability of other employment opportunities, investment on human capital, social status among others. Therefore, effect of population growth on real wage rate is ambiguous. Wage rate of export agriculture (Wex) price of food are considered as other influential variables on $\mathrm{W}_{\mathrm{AG}}$.

The assumptions of the classical regression model necessitate that both dependent and independent variables be stationary and the errors have a zero mean and a finite variance. In the presence of nonstationary variables, the regression relationship is spurious (Granger and Newbold, 1974). When data sequences are stationary the classical regression model is appropriate. When data sequences are stationary the classical regression model is appropriate. However, most economic series tend to exhibit nonstationary stochastic process of the 
form:

(4)

$$
X_{t}=\alpha+\beta X_{t-1}+e_{t}
$$

Where, $\alpha$ is a constant, $\beta=1$, and $e_{t}$ is an error term. Since $\beta$ is unity, $\mathrm{X}$ is said to have unit root. If $\mathrm{Xt}$ is non-staionary, the variances may become infinite and any stochastic shock may not return to a proper mean level. It was a common practice to make non-stationary variables stationary by differentiating. Engle and Granger (1987) provide tests for stationarity of data series as the augmented Dickey-Fuller (ADF) test. (5)

$\Delta X_{t}=\alpha+\delta X_{t-1}+\sum_{t-1}^{k} \beta X_{t-1}+e_{t}$

The ADF test is based on tstatistics on $\delta$ obtained from OLS regression of data series in the form of equation 2. Diffrencing may make non-satationary variables stationary but if the residual sequence contains a stochastic trend, the regression is spurious. Engle and Granger (1987) showed that it is quite possible for a linear combination of integrated variables to be stationary. In this case the variables are said to be cointegrated.
Cointegration refers to a linear combination of nonstationary variables and all variables must be integrated of the same order. Nonstaionary variables which are integrated in the same order with a stationary residual sequence show presence of long-run relationship (Engle and Granger, 1987). Once the stationary properties of the data series are tested, linear combinations of the integrated series are tested for co-integration. If a linear combination of data series expressed as:(6)

$Y_{t}=\beta_{0}+\beta_{1} X_{1 t}+\beta_{2} Z_{t}+\ldots+e_{t}$

If the equilibrium is meaningful it must be the case that the error is stationary. If data series are cointegrated, then there must exist an error correction representation. Conversely, if an error correction model provides an adequate representation of the variables, then they must be cointegrated (Engle and Granger, 1987). The Engle and Granger (1987) method is based on assessing whether estimates of the equilibrium errors appear to be stationary ${ }^{1}$.

\footnotetext{
${ }^{1}$ The presence of more than one long-run relationship (many co-integrating vectors) and this is not captured by the Engle and Granger procedure. Johansen (1988) presented a system approach to overcome this shortcoming. If all componets of $x_{t}$ are integrated of order $d$ and there exists a vector $\beta^{\prime}$ such that the linear combination $\beta^{\prime} x_{t}$ of order (d-b) where $\mathrm{b}>0$. $\beta^{\prime}$ is called co-integrating vector. If $x_{t}$ has $n$ components there may be $n-1$ linearly independent co-integration vectors. If multiple co-integrating relationships are found it may not be possible to identify the behavioural relationships from the reduced-form (see Enders 1995 for details).
} 
Furthermore, the short-run dynamics can be described by the error correction representation (Granger representation theorem). The basic idea behind the error correction model is that the movement of the variables in any period is related to the previous period's gap from long-run equilibrium. The error correction mechanism captures the short-run dynamics while making them consistent with long-run dynamics.

If $Y_{t} \sim \mathrm{I}(1)$ and $X_{t} \sim \mathrm{I}(1)$ and $Z_{t}=$ $Y_{t}-b X_{t}$ is $\mathrm{I}(0)$ then $\mathrm{X}$ and $\mathrm{Y}$ are said to be co-integrated. The Granger representation theorem says that in this case $\mathrm{Xt}$ and $\mathrm{Yt}$ may be considered to be generated by error correction representation of the form:

$\Delta X_{t}=b_{1} Z_{t-1}+\operatorname{lagged}\left(\Delta X_{t}, \quad \Delta Y_{t}\right)+e_{1 t}$ $\Delta Y_{t}=b_{2} Z_{t-1}+\operatorname{lagged}\left(\Delta X_{t}, \quad \Delta Y_{t}\right)+e_{2 t}$

Where at least one of $b_{1}$ and $b_{2}$ is non zero; $e_{1 t}$ and $e_{2 t}$ are white-noise errors.

\section{Empirical Estimation}

The model is estimated using data for the period 1977-2001. Data on agricultural wages are obtained from cost of cultivation of agricultural crops (COC), Department of Agriculture (DOA), Sri Lanka. Capital formation in agriculture is approximated by the investment in irrigation and land development. Capital stock in nonagriculture is approximated by dividing the real value added in nonagriculture by total labour force in the non-agricultural sector. Wage rates for export agricultural sector and capital stock of non-agricultural sector are estimated from data in annual reports of the Central Bank, Sri Lanka (CBSL). Price of agricultural output is calculated from data in COC and data obtained from DOA, Sri Lanka. The price of agricultural tradables shows a declining trend and it is assumed to be determined by exogenous factors. The results of the ADF test for unit root are presented in Table 4.

$\begin{array}{ccc}\text { The Engle and } & \text { Granger } \\ \text { procedure } & \text { defines } & \text { long-run }\end{array}$ equilibrium relationship in wage formation in the DAS. The statistical appropriateness of the residuals is tested with ADF test (support cointegration), Box-Pierce (1970) statistics (residual autocorrelation) and $F$ test (Chow, 1960) statistics for structural stability. The Box-Pierce statistics results indicate that null hypotheses of non-autocorrelation can be accepted. The structural stability of the residuals is guaranteed by the results of the F test (Table 5).

After, normalization by wage, the following long-run relationship is selected (7).

$W_{A G}=0.68+0.47 e_{w t-1}+0.52 W_{A G_{t-1}}+0.17 K_{N A-1}$ (0.96) (1.98) (3.38) (2.6)

Where $\mathrm{e}_{\mathrm{w}}$ is the error correction term. 
Table 4: ADF test for unit root

\begin{tabular}{llccc}
\hline \multirow{2}{*}{ Variables } & \multicolumn{2}{c}{ Levels } & \multicolumn{3}{c}{ First-Difference } \\
\cline { 2 - 5 } & \multicolumn{1}{l}{ Without Trend } & With Trend & Without Trend & With Trend \\
\hline $\mathrm{P}_{\mathrm{AT}}$ & -1.78 & -1.52 & -3.58 & -3.62 \\
$\mathrm{~W}_{\mathrm{AG}}$ & -2.33 & -2.33 & -3.95 & -3.87 \\
$\mathrm{~K}_{\mathrm{NA}}$ & -1.78 & -1.73 & -4.43 & -4.98 \\
$\mathrm{FP}$ & -2.24 & -2.24 & -5.25 & -5.09 \\
$\mathrm{~W}_{\mathrm{EX}}$ & -1.25 & -1.39 & -5.33 & -5.03 \\
$\mathrm{~W}_{\mathrm{NA}}$ & -0.72 & -2.15 & -5.12 & -5.01 \\
$\mathrm{~K}_{\mathrm{AG}}$ & -1.24 & -2.12 & -3.40 & -3.24 \\
\hline
\end{tabular}

Note: The ADF critical values at 5\% level of significance are -2.88 and -3.44 respectively for without trend and with trend (Mackinnon (1991))

Table 5: Engle and granger tests for long-run equilibrium

\begin{tabular}{lllll}
\hline Regressor & \multicolumn{4}{c}{ Independent Variables } \\
\cline { 2 - 5 } & $\mathrm{W}_{\mathrm{AG}}$ & $\mathrm{W}_{\mathrm{NA}}$ & $\mathrm{W}_{\mathrm{EX}}$ & $\mathrm{K}_{\mathrm{NA}}$ \\
\hline $\mathrm{W}_{\mathrm{AG}}$ & - & -0.17 & -0.21 & 1.40 \\
$\mathrm{~W}_{\mathrm{NA}}$ & -0.20 & $(-1.09)$ & $(-0.63)$ & $(4.53)$ \\
& $(-0.9)$ & & 0.31 & -0.49 \\
$\mathrm{~W}_{\mathrm{EX}}$ & -0.08 & 0.11 & $(0.89)$ & $(-1.09)$ \\
& $(-0.6)$ & $(0.89)$ & - & 0.66 \\
$\mathrm{~K}_{\mathrm{NA}}$ & 0.34 & -0.10 & 0.39 & $(2.81)$ \\
& $(4.5)$ & $(1.09)$ & $(2.81)$ & \\
Intercept & 1.76 & -4.82 & 6.52 & -19.7 \\
& $(0.18)$ & $(-0.53)$ & $(10.14)$ & $(-1.02)$ \\
$\mathrm{R}^{2}{ }_{\text {(adj) }}$ & 0.66 & 0.29 & 0.36 & 0.74 \\
$\mathrm{DW}$ & 0.95 & 0.67 & 1.18 & 0.97 \\
$\mathrm{ADF}$ & -3.51 & -1.69 & -4.32 & -2.46 \\
$\mathrm{~F}$ test & 2.17 & 3.25 & 1.56 & 3.78 \\
Box-Pierce(Q test) & 6.25 & 14.12 & 5.46 & 22.3 \\
\hline
\end{tabular}

Note: DW is the Durbin-Watson statistics, The ADF critical values at 5\% level of significance are -2.88 and -3.44 respectively for without trend and with trend (Mackinnon, 1991). The critical value for $F$ test is 2.79 (Chow, 1960) while the critical value for the Box-Pierce statistics is 15.5 (Box and Pierce, 1970). The figures in parenthesis are t-statistics.

The figures in parenthesis are t-statistics. The staionarity test proved that the residual sequence is stationary at $5 \%$ level. This is an equilibrium relationship to which variables have a tendency to return in the long-run. The wage rate of the previous year has an important influence over the wage rate determination of the following year. The wage rate of the export agricultural sector shows no 
significant influence on wage formation in the DAS. The capital formation of non-agricultural sector has significant influence on the wage rate of the DAS. Liberal trade policies in Sri Lanka contributed to an expansion of the service sector and the manufacturing sector. Expansion of the service sector created significant employment. The manufacturing sector has been encouraged through foreign direct investments and capital inflow has been increased with the inflow of remittances. The results indicate that an increase in capital stock in non-agriculture by 1 percent will increase the real wage rate of agriculture by 0.17 percent. The expansion of the non-agricultural sector has significantly contributed to the increase of the real wage rate in the DAS. This indicates that the induced change in the economy attracts labour from the DAS.

\section{Concluding Remarks}

This study examines the influence of the economic environment on real wages of the DAS during the post reform period. The real wage rate of the DAS has been increasing, despite the existence of unemployment in the rural sector. The real price of output in the DAS and real wage rate in the non-agricultural sector show a declining trend. Engle and Granger methodology is used to determine the relationship between the real agricultural wage rates, capital formation in nonagriculture and wage rate of export agriculture. Presence of cointegration among selected variables was established and long-run relationship was estimated. The common belief is that the wage rate in the export agricultural sector has a pervasive effect on wages in the DAS. On the contrary, the result of this study shows that the real wage rate of the export agricultural sector has no significant effect on wage formation in the DAS. The most important policy implication is that the wage rate in the DAS could rise with the expansion of non-agriculture. Capital inflows in the form of foreign investments and remittance would further expand the non-agricultural sector. Therefore, further expansion of the non-agricultural sector would have a strong influence on wage rates and output levels of the domestic agricultural sector. Hence, the structural factors have strong influence on the wage rate of the domestic agricultural sector. Prudent macroeconomic management may not be sufficient to halt the current trend in the real wage rate. The capital formation in non-agriculture induces more inter-sectoral labour migration and it reduces the supply of labour to the DAS. Inter-sectoral income differences, human capital development and physical capital 
could have strong influence on the inter-sectoral labour movements. Increase in labour productivity, suitable farm mechanization, institutional changes related to land (Yaya programme) and development of new institutions related to agricultural labour (reduce uncertainty (strengthening farmer pension schemes), attract young labour force to agriculture, etc.) would help to mitigate the negative influence of wages.

Some caveats need to be made with respect to the analysis. The period investigated here is quite short. However, available data provide very useful information on wage formation in the domestic agricultural sector of Sri Lanka. The change in the labour force or the basis for the observed histeresis is not investigated in detail. Detail analysis is required that include the changes of human capital development, social and demographic changes in the rural sector. Extra benefit can be obtained by using adequate time series estimation procedure.

\section{References}

Ahmad, I. (1981). Wage Determination in Bangladesh Agriculture, Oxford Economic Papers. 33:298-323.

Boyce, J. (1989). Population Growth and Real Wages of
Agricultural Laboureres in

Bangladesh. Journal of Development Studies. 25:467-489.

Davidson, R. and J. MacKinnon. (1993). Estimation and Inference in Econometric. Oxford University Press.

Dixit, A.K. (1989). Entry and Exit Decisions Under Uncertainty, Journal of Political Economy. 97:620638.

Dixit, A.K. and R. Rob.] 1994). Switching Costs and Sectoral Adjustments in General Equilibrium with Uninsured Risk. Journal of Economic Theory. 62:48-69.

Enders, W. (1995). Applied Econometric Time Series. John Wiley \& Sons Inc.

Engle, R.F. and C.W.J. Granger. (1987). Cointegration and Error Corection: Representaion, Estimation and Testing. Econometrica. 39:199-211.

Granger, C.W.J and P. Newbold. (1974). Spurious Regression in Econometrics. Journal of econometric.. 3:345-364.

Johansen, S. (1988). Statistical Analysis of Cointegration Vectors. Journal of 
Economic Dynamic and Control. 12:231-254.

Karunagoda, K., K. Hiroichi and I. Shigeru. (2005). The Impact of Liberal Economic Policies and the Expansion of the Non-tradables Sector on Sri Lankan Agriculture. Journal of Agricultural Development Studies. The Japanese Society of Regional and Agricultural Development.

Larson, D. and Y. Mundalak (1997). On the Intersectoral Migration of Agricultural Labour. Economic Development and Cultural Change. University of Chicago: 295-317.

Lewis, W.A. (1954). Economic Development with Unlimited Supplies of Labour. Manchester School of Economics and Social Studies. 22:139-191.

Leibenstein, H. (1957). The Theory of Underemployment in Backward Economies. Journal of Political Economy.

Majumdar, D. (1959). Marginal Productivity Theory of Wages and Diguised Unemployment. Review of Economic Studies.
MacKinnon, J.G. (1991). Critical Values for Cointergration Tests in R.F. Engle and C.W.J. Granger, Long-run Economic Relationships, Reading in Cointegration, Oxford University Press Inc, New York.

Rama, M. (2003). The Sri Lankan Unemployment Problem revisited Review of Development Economics. 7:510-517.

Richards, T.J. and P.M. Patterson (1998). Hysteresis and the Shortage of Agricultural Labour. American Journal of Agricultural Economics. 80:683-695.

Sah, R.K and J.E. Stiglize. (1987). Price Scissors and the Structure of the Economy. Quarterly Journal of Economics. 102:109-134.

Seers, D. (1971). Matching Employment Opportunities and Expectations: $a$ Programme of Action for Ceylon, International Labour Office, Geneva (1971).

$\begin{array}{rrr}\text { Wikramasinghe, } & \text { Y.M., } & \text { M.B. } \\ \text { Agalawatte, } & & \text { K.S. } \\ \text { Karunagoda } & \text { and N.F.C. } \\ \text { Ranaweera. } & (1994) . & \text { The }\end{array}$


Economics of Reasource Use in farm Activities in

Relation to Off-farm

Employement: Techanical and Price Efficiency Aspects. A paper presented at the final workshop of the Rural Diversification Project, Socio Economic and Planning Center, Department of Agriculture, Sri Lanka. 